\title{
The Use of Total Physical Response Strategy at Junior High School of SLBN South Curup, Rejang Lebong
}

\author{
Paidi Gusmuliana \\ IAIN Curup \\ paidigusmuliana@gmail.com
}

\begin{abstract}
This research aims at investigating implementation of Total Physical Response (TPR) strategy at Junior High School of SLBN Curup Selatan, for the problems came from phenomena occurred on the students with special needs who had different disability such as tunanetra/ blind students and Tunarungu/ deaf and mute students in Learning English. The objectives of this research were to find out how implementation and difficulties faced the students of using TPR strategy .Then the researcher used Qualitative research with a case study of descriptive Qualitative. The subjects were two of English teachers who managed or taught them by using TPR strategy. The techniques of collecting data in this research were observation and interview. In this case, the researcher used observation checklist and interview guidance. There were some steps to analyze the data: data reduction, data display and drawing conclusion/ verification. The result of the implementation of Total Physical Response at SMPLBN Curup Selatan that teachers could implemented Total Physical Response strategy effectively in which the students were able to receive information easily and were more enjoyable in learning English. Then the factors that could influence the difficulties for them to understanding material were from their low capacity to process information, and they need special treatment and sufficient time in learning English.
\end{abstract}

Key words: Total Physical Response Strategy

\section{INTRODUCTION}

English is one of the widely used as international languages. In countries where English is neither the first nor the second language, it is

\author{
ENGLISH FRANCA : Academic Journal of English Language and Education \\ Vol. 2, No. 2, 2018, IAIN Curup \\ P-ISSN 2580-3670, E-ISSN 2580-3689
}


also learned as the foreign language for practical necessary uses of communication. It can serve as the language of instruction in higher education. As English is the language used as a medium of communication and as an international language first used to interact with others around the world (http://www.sekolahbahasainggris.com). It is a medium of communication which can help people to interact, converse, and share to other people. English is as an international language that's why it is possible to everyone to communicate with other people around the world if someone has an ability to use English. The ability in using English is very important to everyone. This is one of the ways to improve human resources.

School in major Indonesian dictionary is a building, teaching and learning institutions as well as a place to receive and give lessons (Kamisa, 1997, p. 482).Schools are educational institutions that formally conducting lessons in a systematic, planned, deliberate, and purposeful, conducted by professional educators, with a program that is poured into a particular curriculum followed by the student at any particular level (Suwarno, 2013, p. 42).

Based on definition of school above, it is very important for students who want to learn at the school to add the knowledge for themselves, but there are several kinds of schools in this world. Outstanding education explains that education is directed at the development of attitudes and the ability of the child's personality, talents, mental abilities, and physical to reach their optimum potential(UU Sistem Pendidikan Nasional(20),2013). Outstanding education aims to equip students with special needs to be able to play an active role in society.

Each child is classified and incorporated into the class of their needs and necessities are provided at the school that suits their needs. The school then they are tough by faculty members who specialize in their respective needs, by means of tools required in accordance with the needs of their group (lidya, 2011).A student with special needs is "student who has a disability of an intellectual, physical, sensory, emotional or behavior nature, has a learning disability or has special 
gifts or talents, as defined in Special Education Services: A Manual of Policies, Procedures, and Guidelines (Colombia, 2009,p.34).

Teachers in the classroom have to treat them more patiently and with one by one until the child understand what has been delivered.However, students feel that English is difficult to learn because English as a foreign language. Recently, English is one of the important subject at school. It is shown from the teaching schedule of English subject that is taught from elementary until university level in Indonesia. For especially, The student in SMPLBN Curup Selatan have different ability to catch the material. Then in teaching learning process the teacher in visual impairment Student or Tunanetra, the student who has visualimpairment the teacher use listening to give instruction and will make some strategies, but they have high ability. In other word, although they can not see something in front of them, they have a good memorize to remind the lesson which the teacher teaches them.

Communication Deafness or Tunarungu, cause of this lessens will cancel process to get knowledge. Lowness of intelligence level deafness student was not come from their low intellectual but the inteligence does not have chance to grow up. Mentally retarded Student or Tunagrahita is student who has low intelligence in process learning subject. In SMPLBN Curup Selatan all students in this disability feel difficult to catch something because they cannot do something. Consideration from others, the most students who has low value is mentally retarded student.

Additionally, the teacher has been using one of strategies in this school to make learning English easily. It is called Total Physical Response (TPR) where it is a language teaching strategy on built around the coordination of speech actions and movement and learning language in motor activity(Richard,p.3).From explanation, The Total Physical Response can be used for teacher to teach or reduce stress of students in learning English.

Morever, according to Asher, students will learn more when they are relax (Asher,p.3). Indeed, students learn more when they are relax and free from stressful situation. In the country, when the students are 
in stress condition, they are not able to devote full energy to learn. Based on pre observation one of schools that has difficulty in giving material or instructional material English Lesson is SLBN Curup. English lesson has been taught once a week. There are three kinds of students who have disabilities. The first of the obstacles is visual impairment student (tunanetra) who could not see something or could not see what the teacher acted. The student just could hear what the teacher said. They could not do anything and did something like body language which use by a teacher besides a hearing. The second obstacle is mentally retarded student (Tunagrahita). Students who had this disability had limitation in intellectual functioning. The teacher had been teaching by totality but the student difficult to understand and catch the material because they have low IQ.

The third is communication deafness where a student could not hear the teacher sound or saying. Student just can write, read and see something that the teachers act a movement. The student often got miss understanding about the material because they cannot complete the entire thing that the teachers want. It is not based on the teacher material and necessary. They just can catch and understand by using their own ability. Furthermore, the teacher did approach to the student one by one to make them understand about the material. Based the result of interview, she said that there were a lot teaching media used for teaching such video, pictures, real object. However, because the fact that the students from different disabilities were joined into one classroom. It made the teacher herself got difficulties to use those media. Fortunately, she used TPR strategy regularly that she got a significance or effective teaching in the classroom. Yet, she still got problematic how to manage students when she implemented TPR Strategy, for the students should get special treatment owing to their limitations. Moreover, it was due to some factors such the students had low capacity to receive information and had body disability to do something. Based on the phenomena and explanation above, the researcher needed to know the implementation and they have obstacles of using TPR strategy in teaching English at SLBN Curup Selatan 


\section{THEORITICAL FRAMEWORK}

The Physical Response is a strategy of teaching language using Physical movement to react to verbal input in order to reduce students' inhibitions and lower their affective filter. It allows students to react to language without thinking too much, facilities long term retention, and reduces student's anxiety and stress (Simon, 1977,p. 1). The Total Physical Response (TPR) involves the students listening and responding to commands given by the teacher such as 'sit down' and 'walk," with complexity of the commands growing over times as the class acquires more language. Student speech is delayed, and once student indicate a willingness to talk them initially give commands to other students.The Total Physical Response (TPR) involves the students listening and responding to commands given by the teacher such as 'sit down' and 'walk," with complexity of the commands growing over times as the class acquires more language. Student speech is delayed, and once student indicate a willingness to talk them initially give commands to other students (Setiyadi, 2006). From explanation above, itcan beconcluded that the Primay School can improve their students' ability in English by using total physical response that helps them to the better understand.

\section{The objective of Total Physical Response}

A strategy in teaching or learning process should be develop in order to will get better purpose for a betterr study.TPR had been developed to improve the better result in teaching learning process of a new language. In learning to communicate a foreign language the TPR belieevest in the importance of having the student enjoy their experience. According to Larsen-Freeman TPR was developing in order to reduce the stress people when studying foreign languages and thereby encourage students to persist in their study beyond a beginning level of proficiency (Larsen-Freeman,p.113). Ricard and Rodger say the general objectives of total physical response are to teach oral proficiency at a beginning level. Comprehension is a mean to an end, and the ultimate aim is to teach basic speaking skills. TPR aims to produce learners who are capable of an uninhibited communication that is intelligible to a native speaker (Jack, 1986). Meanwhile, in process 
learning new language by using TPR was developing some a result too be better. A student reduce their stress in the class when the situation was bad. In using some tools here, they can enjoy in their experience.

\section{The Teacher, Learner's Role in TPR and Instructional Materials}

\section{The teacher Role}

The teacher plays an active and direct role in Total Physical Response. The instructor is the director of a stage play in which the student are the actor in the class. Although, they are different students but the teacher should use the same strategy to teaching. It is the teacher who decides what to teach, who a presents and models the new material, and who select supporting materials for classroom use.

\section{Learners Role}

Every learner in Total Physical Response has the primary roles of listeners and performer. They listen attentively and respond physically to command given by the teacher. Listeners have little influence over the content of learning, since content is determined by the teacher, who must follow the imperative - based format for lessons. According to Larsen and freeman, students are imitators of the teacher's nonverbal model. There will be a role reversal with individual students directing the teacher and other students (Diane Larsen, p.113).In TPR, learners monitor and evaluate their own progress. They are encouraged to speak when they feel ready to accept the lesson by using their selves.

\section{The Role of Instruction Materials}

There is generally no basic text in Total Physical Response course. Material and regalia play in increasing role. However, in later learning stages, for absolute beginners, lessons may not require the use of materials, since the teacher's voice, action and gestures may be a sufficient basic for classroom object, such as books, pens, cups, furniture. As the course develops, the teacher will need to make or collect to supporting materials to support teaching point. These may include picture, reality, sliders and word chart (Richard,p.115). 


\section{The Characteristic of Total Physical Response}

Before the researcher are going to implementation the TPR strategy for teaching a foreign language, the teacher should understand what are the characteristic of this strategy. Concerning TPR, Ommagio mentions the characteristics of TPR; they are as follow (Ommagio, 1986):

a. The teacher directs and the students acts in response

b. Understanding of the spoken language must be developed in advance of speaking.

c. Understanding and retention is best achieved through movement of the students' bodies in response to commands

d. Listening and physical response skills are emphasized over oral production

e. Students should never be forced off speak before they are ready. As the target language is internalized, speaking will be emerged naturally

f. Grammar and vocabulary are emphasized over other long areas. Spoken language is emphasized over written language

g. Whenever possible, humpier is injected into the lessons to make the learners more comfortable in learning languageuage.

The characteristic of Total Physical Response is very suitable for some student who has disabilities. They are students who always difficult to learn but in this character student will act in response. The teacher gives them stimulation directly in learning. For instance, "touch your hand" they will be act in speaking but just for student who know what the teacher say. There have been done of previous researchers who conducted the implementation of Total Physical response strategy in learning English.

Sugito, in his researcher entitled "Teaching Listening to the Fourth Grade of Elementary School Students by using the Total Physical Response strategy. This research is aimed to know: the extent of 
students' understanding toward teaching and learning listening comprehension material by using the total physical total response strategy and the student' attitude towards teaching and learning process. In teaching and learning process, teacher should give comprehension in put in order to make their student grasps the material given. More important than that, teacher should avoid a barrier that may prevent their, from learning and it can be high anxiety or low motivation. And enjoyable strategy is needed act accordingly (Sugito, 2004).

Eka Febrianti conducted a research entitle " Teacher Technique in teaching English for retarded student (study case at SLB Junior High School GI Mataram (Musirawas). The Study that use is descriptive qualitative." The object of this study was English teacher for physical handicapped student, mental retarded and blind student. First, for physical disabled students, teacher used speech technique, answer question, and memorize vocabulary. Second, in teaching English for student with mental retardation, teacher use speech technique and answering question. The last, to teach blind students teacher uses speech technique, answer and question and assignment (Febriyanti, 2013).Based on explanation some researches above, this research, the writer focused on implementation of TPR strategy and some difficulties in teaching student by using TPR strategy with student in special need by differences.

\section{RESEARCH METHODOLOGY}

The present research is descriptive research. It is involve in qualitative research. In other words, this research is descriptive research which present by qualitative way. Qualitative research is research studies that investigate the quality of relationship, activities, situations or material (Jack, 2009,p.422).It means that the data which collected in this research is about situation and condition of the research field as the important aspect of the research. The descriptive event use one variable and it does not compare with one or more variable, and it focused on the factual data.Descriptive research means a 
reasearch focused in describing any situation or condition in population, systemaically, factually, and accurately(Zuriah, 2007).So, the reason on researcher chose qualitative in implementation of TPR Strategy to know the activities, situation and material that they use in process. And the researcher will only present all the fact objectively based on the data that is obtained from: observation and interview.

This research was carried out at SLBN Curup Selatan. There are two English Teachers who teach in this school with different grade. So, the researcher chose both of the as the subject involved to complete the data of the implementation of using TPR Strategy. According to Creswell, "The varied nature of qualitative form of data they are place into: observation, interviews and questionnaires, documentations, audio-visual material (Creswell, 2002)." In this research, the researcher used observation, interview and documentation, as the instruments of this research to collecting the data. In the process of collecting data, the researcher will identifies and analyzed the data.

The techniques of collecting the data are as follows:

1. Observation: The technique of collecting data that the researcher used observation. Observation data are attractive as they afford the researcher the opportunity to gather 'Live' data from ' live' situation. Like Patton states in Research Method in Education the researcher is given the opportunity to look at what is taking place rather than at second hand(Lois, 2005).In this research, researcher uses non participant observation. Non- Participation means to observer is not directly involved in the situation being observed(Gay, 2000)..It means the researcher does not participate in the learning process which is investigated.

2. Interview: Interview is used for collecting formation which is not obtained from the observation. In this research, the researcher used interview to collect the data for second research question to know the method used by the teachers by selected important way for a researcher to check the accuracy to verify or refute the impressions he or she gained through observation (Cohen,p.445). Interties which used in this research were semi 
structure interview. In this type of in interview, the researcher attempts to achieve a holistic understanding of the interviews' point of view or situation (Dawson, 2002). In other hand semistructure interview the participant is free to talk about what they deems important. For this research, when the researcher want to get the data did interview by using guidelines of interview and also using tape recorder for taken the result from the interview. After all the data is collecting, the researcher write in written text script

\section{FINDINGS AND DISCUSSION}

The researcher presented the finding from observation checklist, and interviewed. This research had been done on May until July 2017. The aims of this research were investigate how the implementation of Total Physical Response strategy is, and difficulties are faced by the students of implementing the total Physical Response at Junior High School SLBN Curup Selatan. The observations were done in two classes of seven grade student (Visual Impairment, and Communication Deafness Student) for 4 meetings in each class. In collecting the data researcher used some instruments such as checklist observation and interview guidance.

\section{The implementation of Total Physical Response at SLBN Curup Selatan}

To know the data or the result, the researcher used checklist of observation. It was aimed at knowing how the implementation of Total Physical Response in this school based on the theory like the procedures of teaching using TPR strategy, Principles, objective of Total Physical Response strategy.

\section{Students with visual impairment / Tunanetra}

In the first meeting on2 ${ }^{\text {nd }}$ May 2017, the researcher observed process of theimplementation Total Physical Response strategy. For visual impairment students could not see something or teacher's movement when they are learning. They just listen what the teacher 
says or commands. The topic is Introducing Yourselves. In the beginning lesson, the teacher does not delay until the students understand to speak generally about spoken language. In addition, the teacher needs something to make stimulus in the beginning lesson. First, the teacher gave a model by introducing herself such as name, address, age, and hobby in front of the classroom Then, students listened what the teacher said and also teacher translated one by one the word that had been taught because the students could not translated the word by their selves in using dictionary. After that, the teacher asked to the students to memorize the material about. From the observation, one student participated well to remember vocabulary.

\section{Example:}

Ona : My name is ona. I live in Dasta. I'm 15 years old. I like Dangdut music.

Friend : What you like in classroom, Ona?

Ona : I like a pen

From example above, Ona tried to share or present the material about introduction. One of the students asked to Ona and He answered the question surrounding them which is very beneficial to supporting the material in the class. Furthermore, teacher who teaches the visual impairment tried to do in some ways to make student understanding of spoken language in order they have bravery to indicate their selves ready to talk in front of the teacher and their friends. Unfortunately, when they did the teacher command to speak, the spoken language was not same to the word and the sentence based on the written as they used brailed. In process of learning, the teacher got better result in teaching new vocabulary. Although the students could not see, they could catch of new language that just listen. Moreover, there was one student who got late to catch instruction from the teacher, for he get retarded mental where he had to listen carefully to process the information. Data from field note that he could associate the 
information from the teacher around three minutes. Finally, the result of interview could be seen as follow:

Researcher: Why does this student get late to catch information from you?

Teacher: Actually, this student got low to get and process the information, for he is categorized as low of intelligent.

It means that the obstacle which is faced that the students has limitation in intellectual functioning, expressed in conceptual, social, and other skill. In the second meeting on $9^{\text {th }}$ May 2017, the topic is Things in the classroom. Based on the observation checklist, the teacher still used steps of TPR strategy instruction in teaching English. There were some activities in the class when process learning was begun. Before the teacher started the process, the teacher reviewed the material before because the aim was to make them remember of some vocabulary. In beginning, prepared some things like pen, pencil, book, bag etc. Then she mentioned one by one in English. Furthermore, she gave to the students to touch that thing. Then, while the teacher spelled the thing one by one, the students then write them into English by brailer letter. In this meeting, the problem was faced by the students such writing which the teacher had to spell the word.

Next, in the third meeting on $16^{\text {th }}$ May 2017. The topic is about Parts of body. In this meeting, the teacher wrote the topic on the whiteboard. She mentioned some parts of body in English, and the students listened to the teacher. After that, the teacher gave model of them with expressions such as this is my head and the students followed the teacher. She also ordered students to touch parts of body by giving instruction. From this meeting, it could be seen that students felt enjoy in process of learning. Unfortunately, based on the result of exercise found that some students got low score. It was because the teacher set the time that they had to finish and submit the result. As a result, some of them could not concentrate well. It means that some of the need more time to finish the items as they have limited capacity. 
At the fourth meeting on $30^{\text {st }}$ May 2017, the material is about animal. The teacher investigates the implementation of this Total Physical response by observation and field note. The teacher used video to make the students more interesting to learn. In this time, the students just heard the song, but it was different from the last time. Although the students listened sound about the English one, but the meaning was just from the animal sound. So, they guest what is the name of animal is it. After that the teacher asked to the student to answer the sound.

If they have been ready to answered and understand about the meaning so it is successful to reach the better result from the fourth meeting. Because Listening is included during most of the stages of the TPR strategy: in the presentation of vocabulary, in students' aural recognition of said vocabulary and finally in the practice stage where the teacher gives commands or information students need to respond to in different ways. In this time the teacher used extra energy to talk and they should make the student know how to say without writing. The student is a type of persons who likes to listen, it makes her becomes a listener type. She loves to hear than observe, because she interest in language is hearing many sound. The teacher did not want to force the student to accept much material that would make them stress to process learning. They just reviewed the material from the first meeting until the end of the meeting in the class.

\section{Deaf and Mute Students}

In the first meeting on $5^{\text {th }}$ May 2017, the topic was about Days. Before the learning process was started, the teacher invited student to follow the instruction to artedgive Pray to the God in order to they gave the blessing from Allah. After that, the teacher wrote the material in the whiteboard about the vocabulary of Days. In write the material, teacher did not write about the English one but also she wrote the Indonesia and Alphabet of the vocabulary. To make the student more understand and easier to read of it. In the second meeting on $12^{\text {th }}$ May 2017, based on observation the teacher still invited the student to pray to the God. They were talk about introduce yourselves. The teacher wrote the material and read all the written by using body language. The students responded the material by using body language and response by 
physical. Finally, in learning process the student who could not remember or understand the material in the class. But the teachers still do the best for students in order they could enjoyed in the class. On the other hand, the main problem for the teacher in handling the students was to control the students who are need special treatment and attention.

Based on activities in the class during four meetings, it could be concluded that two of English teacher used Total Physical Response strategy, but both of them used different ways. For example, the teacher of blind students mostly used instruction model and audio to make them involved in learning process. In addition, she gave real object that students can touch those things. The second one is teacher of deaf and mute students. She used command and instruction by physical movement. Then she must write spelling how to pronounce words into Indonesia language.

\section{The Students' difficulties of Implementation Total Physical Response Strategy at SLBN Curup Selatan}

Based on the interviewed from the finding at $16^{\text {th }}-17^{\text {th }}$ June 2017 the students got difficulties to understand materials by implementation TPR strategy in SLBN. The researcher got the data from teachers interview about the difficulties based on part of TPR strategy that consist of the Principles, the Objectives, the teachers, learners roles and instructional materials and characteristic of Total Physical Response Strategy. From blind students, they could not see what the object is, and they got difficult to understand the abstract word such days in a week. Furthermore, it can be seen from the answered of the questions list in interview. The activity of the difficulties result also show that the teacher felt difficult in implementing the process of Total Physical Response. It was caused students who have different disabilities. The student had different level of difficulties in learning process. It was from the background the students who have different disabilities. So the implementation of Total Physical Response should have variety based on students with disabilities. It could be seen from the result of interview as in the following: 
Researcher : What are the main problem being faced by the blind students in learning English?

Teacher: The Problem comes from their intellectual which some of them only get barrier from seeing something, yet some of them are late to process information from the teacher. Next is that they usually need much time in understanding materials and doing exercise. So, time is also considered for treat them.

From the information above, it means that although the students are included in blind students, they have different intellectual in understanding materials. Therefore, some of them could understand material quickly other than some of them is late to process the information from the teacher.

The result of interview for the mute and deaf students can be seen as follow:

Researcher : What are some problems that students faced in learning English?

Teacher : To be honest, I got some challenging to transfer knowledge for mute and deaf students as I must use sign language, spell the words into Indonesia language. It was because the students cannot hear and speak the words correctly. Moreover, I should treat students as one by one.

It means that the factor that makes students get difficulty learning English which from their intellectual that influence the process of catching information. Based on the interview in implementing the Principles of Total Physical Response. The researcher indicated that who teaches blind students did not have difficulties of this part, but the teacher who teaches mute and deaf students got some difficulties when the teacher did delay just before spoken from students to their understanding of spoken language generally steady extensively. When the teacher wanted to give the student materials in the beginning level, they were very difficult to implement. Then, the teacher have limited about knowledge that give big effect to the students spoken. Therefore, the teacher had difficulties in trying to do so in some ways to the 
understanding of the spoken language utterances made by the instructor in the form of imperative. Because of the teacher have did some ways in learning but they have difficulties to make the student understand. The short age of the media that one of the difficulties in teaching.

Second, based on the interview from objective of Total Physical Response the researcher get the result that and indicated The teacher who teaches blind students felt difficult in implementing Using actionbased drills in the imperative form. It is because the student had not time to do movement in another place. In imperative form to the student action it was difficult to do. The teachers jobs here just say and did dialogue in teaching not others job. The teacher who teaches deaf and mute students had difficulties in teaching oral proficiency at a beginning level. Because in the beginning of the teacher taught language. The teacher should write the alphabet in learning process so if there was not supporting of equipment to teach the student. It was one of the shortages that the teacher found. The teacher also had difficulties to make the student understand. It needs some ways to make the student easier in catching materials. So, from the statement above, that the teacher could not teach the new material in this student. Because every meeting they would forget about the material that had been shared. Next, the teacher felt difficulties in teaching oral proficiency at a beginning level and using comprehension as a means to speaking. Because it was very difficult to make the student understand about the material that had been taught. It was very impossible for this student easy in learning. According to Ricard an d Rodger say the general objectives of total physical response are to teach oral proficiency at a beginning level. Comprehension is a mean to an end, and the ultimate aim is to teach basic speaking skills. Finally, the teacher get differen sifficulties in implementing part by part of this strategiy for the student who have differen dissabilities.

Third, from the interview the researcher got some result from the teachers, learners roles, and instructional material that followed some difficulties from the teacher implementing are. The reseacrher indicate that who teaches blind students got the difficulties from implementing 
in select supporting the material. It is because the teacher could not use supporting material in learning for student visual impairment. Because of them could not see something that the teacher used. In process learning the student could not response and active in the class because the students are listeners not performers. The teacher asked to response what the teacher command for the student who as a listeners by individual. Because in learning the teacher difficult when should teaching the student by nonverbal model. Likes the teacher used some stuff in the class as the normally student.

From interview who teaches deaf and mute students got difficulties in the teacher who decides what to teach and present the new materials. Because the teacher difficulties when they must present the new material every meeting. Whereas, the teacher who decides what to teach and present the new materials. It was difficult to implement in learning English because the teacher should use body language every single time in teaching. The teacher difficult to asked the student response in collectively because the student just could response what the teacher nonverbal movement in teaching. For example, the teacher asked to the student to come to the stage to write what they were talking about.

Learners Role, Every learner in Total Physical Response has the primary roles of listeners and performers. They listen attentively and respond physically to command given by the teacher. Listeners have little influence over the content of learning, since content is determined by the teacher, who must follow the imperative - based format for lessons. And The Role of Instructtion Materials that There is generally no basic text in Total Physical Response course. Material and reality play in increasing role. However, in later learning stages, for absolute beginners, lessons may not require the use of materials, since the teacher's voice, action and gestures may be a sufficient basic for classroom object, such as books, pens, cups, furniture. As the course develops, the teacher will need to make or collect to supporting materials to support teaching point. These may include picture, reality, sliders and word chart. 
Fourth, from the interview the researcher got some result from the Characteristic of Total Physical Response that indicated from the teacher who teaches blind students got difficulties in teacher directs and the students acts in response. So the teacher difficult to asked from the student to act something. Because the teacher could not force the student to give response from their instructions, she felt difficult when teaching should by using body's movement. Student who could not see something surrounding the class or their environment were could not response in physical but they just give response in speaking. Then, the teacher didn't implement the grammar in visual impairment because they just learned about low material to add the knowledge from the teacher. Difficulties from the teacher followed from the student situation. The condition that was not support in learning so it can makes the teacher difficult to enter their full body in implementing this strategy.

The researcher found the result from the interview that who teaches deaf and mute students got some difficulties in implementing that were: Understanding of the spoken language must be developed in advance of speaking. So the teacher needs extra knowledge to teach the student with special needs. When the teacher want to ask the student to response were very difficult because they had not have ability to listen and speak what the teacher command. Certainly, the teacher used to teach grammar in the past time. But the student could not accept all of the material.

According to Omaigo the characteristic are follows The teacher directs and the students acts in response, Understanding of the spoken language must be developed in advance of speaking, Understanding and retention is best achieved through movement of the students' bodies in response to commands, Listening and physical response skills are emphasized over oral production, Students should never be forced off speak before they are ready. As the target language is internalized, speaking will be emerged naturally, Grammar and vocabulary are emphasized over other long areas. Spoken language is emphasized over written language, whenever possible; humor is injected in to the lessons to make the learners more comfortable in learning languagee. 
In order to, every single teacher had differences in implementing some part from this characteristic that have been implemented to student with special needs. Based on the all explanations above, although the researcher got different result from checklist observation and interview, the researcher concluded that the teacher have been implementing The Total Physical Response in student who have special needs. But the implementation was not clear because just some part of the theories that have been implemented. The researcher looked at the implementation of implementing that the teacher have tried to implement this strategy but here the student have different disabilities. So, it can be said that the teacher could not applied all of the theories in every students. Then, the teacher has some difficulties in implementing the strategy in every single student with dissabilities. There were some of the obstacle that the teacher difficult to implement it.

\section{CONCLUSION}

Based on the implementation result in previous chapter, the researcher concluded that the process of implementation TPR strategy the teacher teach the student who have differences limitation. Althought not all of the students can accept all the material by using TPR strategy, but they felt more enjoy when the teacher taught the. In process learning the teacher never forced the students to speak or to response what the teacher command given. Visual Impairment have limitation in seeing something but they have good quality or they are clever than others student. The last student who can not hear and speak in the class, so they use body language and write to make undesrtand the material about. The factors that influence students got difficulties in understanding material are from their intellectual that they have low capacity in catching materials. Therefore, the teacher felt hard to control them all. The factor is the students' special treatment like intensive learning which they need much time to understand materials.

\section{REFERENCES}


Hornby., As. (1947). Oxford Lerner's Dictionary of current English. Oxford: Oxford University.

Smart, Aqila. (2010). Anak Cacat Bukan Kiamat (Metode Pembelajaran \& Terapi untuk Anak Berkebutuhan Khusus). Yogyakarta : Kata Hati.

Columbia, British. (1999). English as a Second Language Learner: A Guide for ESL Specialists. British Columbia.

Robledo, Caranza Tamara. (2017). Teaching English To Students With Special Needs. universidad de salamanca, Issn 244-1333 verbela ano III, numero 2 , bb-115.

Dawson, Chaterine. (2002). Practical Research method. United Kongdom: Deer Park production. Cohen. Lois at al. Research Method in Education, New York: Taylor \&Francis e-Library.

Depdikbud. (2006). Identifikasi dan Evaluasi Anak Luar Biasa. Jakarta: CV Harapan baru.

Efendi, Mohammad. (2006). Pengantar Psikopedagogik Anak Berkelainan. Jakarta: PT Bumi Aksara.

Diane Larsen-Freeman. (Techniques and Principles In Language Teaching. Oxford: Oxford University Prees.

Directorat Pendidikan Luar Biasa (Article). (2008). Mengenai Pendidikan Iklusif. Google Mikrosof Explorer on 1 December 2008.

Tarigan, Henry Guntur. (2009). Metodologi Pelajaran Bahasa I. Bandung: PT Angkasa Bintang.

Richards, Jack and Rodgers. (1986). Approach an Method In Language Teaching, Cambridge: Cambridge Press.

Frankell, Jack R, and Wallen, Norman E.. (1993). How to Design and Evaluate Research in Education, Mc. Grow Hill, International Edition. 
Creswell, John W. (2012). Educational Research (Planning, Conducting and evaluating Quantitative and Qualitative Research), Lincoln: University of Nebraska.

Gay, Lorraine Rumble. (2000). Educatinal Research Competensies for Analysis and Application. New Jersey.

Luois Cohen, lawrence manion and Keith Morrison. (2003). Research Method in Education fifth edition. New York: Routledge Falmer.

Bashir, Muhammad. (2008). Reliability and Validity of Qualitative and Operational Research Paradigm. Pakistan.

Natasha Mack et al. (2015). Research method: A data collectors field guide. US: Agency for International Development (USAID).

Zuriah, Nurul. (2007). Metodologi Penelitian Sosial dan Pendidikan: Teori Aplikasi. Jakarta : Bumi Aksara.

Simon. (1977). Total Physical Response (A Short introduction), Japanese.

Suwarno, Wiji. (2013). Dasar- dasar Ilmu Pendidikan. Jogjakarta: Ar-Ruzz Media.

Lidya, Way. (2016). Pendidikan Luar Biasa. 30 0ktober 2011. accessed 24 oktober 2016.

Alimin, Zainal. (2018). Pendidikan Kebutuhan Khusus. http://zalimin.blogspot.com.

Gunarsa, Singgih. (2006). Dasar dan Teori Perkembangan Anak. Jakarta: BPK gunung Mulia.

Sutjihati, Somantri. (2003). Psikologi Anak Luar Biasa. Bandung: PT Refika Aditama. 
Sugito. (2005). Teaching Listening to the Fourth Graders of Elementary School Student by Using the Total Physical Response method (a case of fourth graders of SDN Jinggotan Kembang Jepara in Academic year of 2004-2005). Semarang: Unpublished Semarang States University.

Octaviany, Yenni. (2007). The Aplication of total physical response method in teaching English vocabulary to the fourth graders of SDN Negero 04 krajangkulon kaliwungu kendal in academic year 2006/2007. Semarang: Unpublised semarang atet university. 